\title{
THE MINISTER AND THE BOY \\ VI. THE BOY'S CHOICE OF A VOCATION
}

ALLAN HOBEN

The University of Chicago

It is practically impossible to overemphasize the importance of the boy's vocational choice. Next to his attitude toward his Maker and his subsequent choice of a life partner this decision controls his worth and destiny. For it is not to be supposed that play with all its virtue, its flourish and exercise of nascent powers, and its happy emancipation into broader and richer living can adequately motivate and permanently ennoble the energies of youth. Until some vocational interest dawns, education is received rather than sought and will-power is latent or but intermittently exercised. Play has a great orbit, but every true parent and educator seeks to know the axis of a given life.

For some boys presumably of high-school age and over, this problem becomes real and engrossing, but for the vast majority there is little intelligent choice, no wise counsel, no conscious fronting of the profoundly religious question of how to invest one's life. The children of ease graduate but slowly, if at all, from the "good-time" ideal, while the children of want are ordinarily without option in the choice of work. But for all who, being permitted and helped, both seek and find their proper places in the ranks of labor, life becomes constructively social and therefore self-respecting. To be able to do some bit of the world's work well and to dedicate one's self to the task is the individual right of every normal youth and the sure pledge of social solvency. Ideally an art interest in work for its own sake should cover the whole field of human labor, and in proportion as each person finds a task suited to his natural ability and is well trained for

${ }^{r}$ Books recommended: Frank Parsons, Choosing a Vocation, Houghton Mifflin Co.; Meyer Bloomfield, The Vocational Guidance of Youth, Houghton Mifflin Co.; Georg Kerschensteiner, Education for Citizenship, Rand McNally \& Co. 
that task does he lift himself from the grade of a menial or a pauper and enter into conscious and worthy citizenship.

Here then, as in the case of the mating instinct, the vocational quest rightly handled forces the ego by its very inclination and success into the altruism of a social order. For it is the misfits, the vocationally dormant, the defeated and those who, however successful, have not considered such choice as an ethical concern of religion that make up the antisocial classes of the present time.

Hence this problem of vocational guidance which is so agitating the educational world comes home to the minister in his work with youth. It may be that he shall find new and practical use for the maligned doctrine of election and that he shall place under intelligent and heavenly commission the ideals and hopes of later adolescence. At any rate where the life career hinges there the religious expert should be on hand. For what profit is there in society's vast investment in early and compulsory education if at the crucial time of initial experiment in the world's work there be neither high resolve nor intelligent direction nor sympathetic coaching into efficiency?

But the importance of vocational choice does not turn upon the doubtful supposition that there is one and only one suitable task for a given youth. Probably there are groups or families of activities within which the constructive endeavor may have happy and progressive expression. Nor, from the minister's point of view, is the economic aspect of the problem paramount. It is true that an investment of $\$ 50,000$ worth of working ability deserves study and wise placing and it is true that the sanction of public education is to return to the state a socially solvent citizen who will contribute to the common welfare and will more than pay his way; but the immediately religious importance of this commanding interest consists in the honest and voluntary request for counsel on the part of the youth himself.

Fortunately in the very midst of a reticent and often skeptical period there comes, through the awakened vocational interest, an inlet into the soul of youth. No religious inquisitor or evangelistic brigand could have forced an entrance, but lo, all at once the doors are opened from within and examination is invited. It is invited 
because the boy wishes to know what manner of person he is and for what pursuit he is or may be fitted. When once this issue is on and one is honored as counselor and friend, the moral honesty and eagerness of youth, the thoroughgoing confession on all the personal and moral phases of the problem in hand are enough to move and humble the heart of any pastor. Such conference solemnizes and reassures the worker with boys, while to have spent no time as an invited and reverent guest within this sacred precinct is to fail of a priesthood that is profoundly beautiful.

Several experiences with both individuals and groups are fresh in mind at this writing. On one occasion a guild of working boys in later adolescence were living together in a church fraternity house, and it was their custom on one evening of each week to have some prominent man as guest at dinner and to hear an informal address from him after the meal. It chanced that on the list of guests there was, in addition to the mayor of their city and a well-known bishop of the Episcopal church, the manager of one of the greatest automobile factories in America. On the occasion on which this captain of industry spoke he told in simple fashion his own experience in search of a vocation. It was of a kind very common in our country: early privation, put to work at thirteen, an attempt to keep him in an office when he longed to have hold of the tools in the shop. In time his request was granted. While he worked he observed and studied the organization of the shop and the progression of the raw material to the finished product. Having mastered the method he left this shop and hired in another, and then in due time in still another shop much to the disgust of his friends. But in reply to their warning that "a rolling stone gathers no moss" he said that that was not his aim. As a result of faithfully following his bent he was ready to respond to the great demand for men to organize and run bicycle factories, and when that demand was followed by the much greater need of doing a similar work in the manufacture of automobiles he was chosen for the very responsible position which he now holds.

There was, to be sure, nothing distinctly spiritual in his story, but after he had finished the young men kept him for two hours answering their questions and there was there revealed to the 
pastor more of their fine hopes and purposes and possibilitiestheir deep-buried yet vital dreams - than he had ever heard unfolded in any religious meeting. Many of these youths were taken in hand in a personal way and are now "making good." Their subsequent use of leisure, their patronage of evening schools, Y.M.C.A. courses, and many other helps to their ambitions testified to the depth and tenacity of good purposes which were timidly voiced but heroically executed. On the other hand, the writer has knowledge of many cases of delinquency in which apparently the deciding cause was the vocational misfit foisted upon the young would-be laborer in the trying years between fourteen and sixteen.

Public education in America is beginning to respond to the need of intelligently connecting our educational product with the world's work. Trade schools for boys and girls, half-time schools, continuation schools, night schools, and in a few cities vocational bureaus are at work, but so are poverty and the helpless ignorance of the hard-pressed home. The children who must in tender years be offered to our rapacious industries are the very children who are without hope of parental counsel and direction.

In New York City 42,000 children between fourteen and sixteen years of age take out their "working papers" every year, and out of $\mathrm{I} 2,000$ to $\mathrm{I} 3,000$ taking out working papers in Chicago annually about 9,000 are only fourteen years of age and I,500 have not yet reached the fifth grade. Many of these walk the streets and degenerate while in search of work or because of such fitful employment as only serves to balk the department of compulsory education which has the power to insist upon school attendance for children of this age if not employed. It is not that work is uniformly bad for these children. Indeed idleness would be worse. And it is not that all of these children are forced to turn out bad. But as a matter of fact children under sixteen are not generally wanted save in positions of monotonous and unpromising employment and their early experience which is quite without reference to taste and native ability is likely to turn them against all work as being an imposition rather than an opportunity. In the long run this cheap labor is the most expensive in the world, and society 
cannot afford to fully release children from school control and training prior to sixteen years of age. Much less can it permit them at any time to approach the employment problem blindly and unaided. Nor should it fail to reduce the hours of labor for such children as fall into permanently unprogressive toil and to organize their leisure as well as to provide opportunities whereby some may extricate themselves.

What is this industrial haste which cuts so much of our corn while it is only in tassel, that drives square pegs into round holes, that harnesses trotting stock to heavy drays and draughting stock to gigs, that breaks up the violin to kindle a fire quickly thoughtless of the music, that takes telescopes for drain pipes and gets commerce-but not commerce with the stars? It is the delirium in which strong men seek the standard American testimonial of genius and ability, namely the accumulation of great wealth; and in this delirium they see labor as a commodity and childhood as a commercial factor. They do not think of people like themselves and of children like their own.

But the minister is the very champion of those higher rights, the defender of idealism, and as such the best friend of an industrial order which is perversely making this expensive blunder and reaping the blight of sullen citizenship and cynical and heartless toil. How can these thousands who because of "blind-alley" occupations come to their majority tradeless and often depleted, having no ability to build and own a home-how can these who have no stake in the country aid in making the republic what it ought to be? Partly they become a public care, expense, or nuisance and largely they constitute the material for bossism and dynamite for the demagogue if he shall come. The economic breakdown because of vocational misfit and the exploitation of childhood usually results in a corresponding moral breakdown. To be doomed to inadequacy is almost to be elected to crime.

Now the pastor certainly cannot right all this wrong, neither will he be so brash as to charge it all up to malicious employers, ignoring the process through which our vaunted individualism, our free field and no favor policy, our doctrine for the strong has disported itself. But is it not reasonable that the minister inform 
himself of this problem in all its fundamental phases and that he both follow and ardently encourage a public-school policy which aims increasingly to fit the growing generation for productive and stable citizenship? Our schools are fundamentally religious if we will have them so in terms of character building, elemental self-respect, social service, and accountability to the God of all.

The "godless schools" exist only in the minds of those who for purposes of dispute and sectarianism decree them so. Furthermore in every effort toward vocational training and sorting, the employer will be found interested and ready to help.

But to come more closely to the place of this problem in church work it must be recognized that the Sunday schools, clubs, and young people's societies offer wider opportunity for vocational direction than is now being used. The curricula in these institutions can be greatly vitalized and enlarged by the inclusion of this very interest and life can be made to seem more broadly, sanely, and specifically religious than is now the case. Suppose that to groups of boys beyond middle adolescence competent and high-minded representatives of various trades and professions present in series the reasons for their choice, the possible good, individual and social, which they see in their life-work, the qualifications which they deem necessary and the obstacles to be met; and suppose further that the ethical code of a trade, profession, or business is presented for honest canvass by the class, must there not result a stimulus and aid to vocational selection and also a more lively interest in the study of specific moral problems? In this way teaching clusters about an inevitable field of interest, about live and often urgent problems, and there is nothing to prevent the use of all the light which may be adduced from the Bible and religious experience.

To describe the method more specifically, the lawyer presents his profession and subsequently the class discusses the code of the bar association; or the physician presents his work and then follows the canvass of the ethical problems of medical practice, and so of the trade-union artisan, the merchant or teacher, the minister, or the captain of industry. All of this is diffused with religion, it has its setting and sanction within the church, it supplements 
for a few, at any rate, the present lack in public education, and it is real and immediate rather than theoretical and remote. Let this be complemented with visits to institutions, offices, plants, courts, and the marts and centers of commercial, industrial, and agricultural life, and, best of all, cemented in the personal friendship, practical interest, and sponsorship of an adult and wise counselor who helps the boy both to the place and in the place, and, within the limits of the rather small constituency of church boys at least, there is guaranteed a piece of religious work that is bound to tell. For surely every legitimate interest of life is religious when handled by religious persons, and the right moral adjustment of the whole self to the whole world, with the emotion and idealism inhering in the process, is the task and content of religion. 